\title{
Has Arabic Language Learning Been Successfully Implemented?
}

\section{Zurqoni}

Institut Agama Islam Negeri Samarinda, Indonesia, zurqoni@iain-samarinda.ac.id

\section{Heri Retnawati}

Universitas Negeri Yogyakarta, Indonesia, heri_retnawati@uny.ac.id

\section{Syarifatur Rahmatullah}

Institut Agama Islam Negeri Samarinda, Indonesia, syarifaturrahmatullah@gmail.com

\section{Hasan Djidu}

Universitas Sembilanbelas November Kolaka, Indonesia, hasandjidu@usn.ac.id

\section{Ezi Apino}

Universitas Negeri Yogyakarta, Indonesia, apinoezi@gmail.com

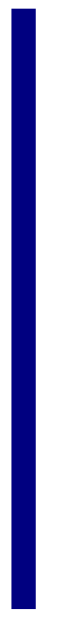

This study aimed at evaluating the implementation of Arabic language learning in Islamic High School (Madrasah Aliyah or MA). This qualitative research applied a phenomenological qualitative approach. The data were collected through Forum Group Discussion (FGD), questionnaires, and in depth-interviews. The participants were 27 Arabic teachers, 9 principals, and 45 students from 9 MA in 3 provinces in Indonesia: East Kalimantan, Special Region of Yogyakarta, and West Nusa Tenggara. The data were analyzed using a Bogdan and Biklen model to obtain the understanding and the interpretation. The result showed that Arabic language learning could not be categorized as "success". The teachers and students experienced some difficulties during the learning process. Those difficulties were caused by a number of factors such as input of students who were unable to read Arabic fluently and basic vocabulary mastery, Arabic verb modifications, limited learning hours for non-boarding MA's students, limited learning facilities, and incomplete environmental supports to give the students' opportunity to speak more in Arabic. Several recommendations for Arabic learning improvements are also discussed accordingly.

Keywords: evaluation of learning Arabic, teachers' difficulty, Madrasah Aliyah, Arabic, language learning

Citation: Zurqoni, Retnawati, H., Rahmatullah, S., Djidu, H., \& Apino, E. (2020). Has Arabic Language Learning Been Successfully Implemented? International Journal of Instruction, 13(4), 715730. https://doi.org/10.29333/iji.2020.13444a 


\section{INTRODUCTION}

Arabic is one of international languages besides English commonly used in legal sources such as Qur'an, Hadith, Ijma, and Qiyas, or other scientific sources. Understanding Arabic is one of the requirements to study various legal sources. In Indonesia, Arabic is a compulsory subject in Islamic Schools (madrasah), for instance, Islamic Elementary School (Madrasah Ibtidaiyah, MI), Islamic Junior High School (Madrasah Tsanawiyah, MTs), or Islamic High School (Madrasah Aliyah, MA). A current fact shows that the students' Arabic skills in Indonesia still cannot be categorized as 'good' indicating that an Arabic learning process is not successful enough (Adila, 2019, Kuraedah et al., 2018; Wekke, 2015, 2017). To overcome this problem, an action is needed to diagnose the problems' factors.

The current development of civilization causes various impacts and changes in the structure of human life. Ease of access to technology, information, and communication allows anyone to access some services more easily without spending much time, cost, and energy. As an example, a lot of sophisticated communication devices have someone to interact easily with one another anywhere, anytime, and even at a distance. However, some irresponsible people abuse those technologies, information, and communication advances to commit various crimes. It means that the emergence of new problems is one of the impacts of those advances. In this case, human interaction patterns have changed much. Therefore, the structure of human life needs a law to control human behavior.

In Islamic civilization, Qur'an and Hadith are the first and foremost basic-law to control the life structure. Additionally, Ijam and Qiyas are also as the basic-law supplement. Qur'an and Hadith not only control worship or ritual worship to the Creator, but also control an interaction pattern between human and human, and even between human and nature. Furthermore, Qur'an is also called "the mother of all knowledge" since it is the main source of various sciences (Zailani et al., 2014). Qur'an is revealed in Arabic to human being and so are Hadith and other Islamic references. Thus, Arabic language learning is one of ways to understand the content of Qur'an, Hadith, Ijma, Qiyas or other Islamic references (Mat \& Wan Abas, 2016).

Arabic is one of the International languages instead of English. In this case, learning Arabic like other languages aims to master four skills such as speaking, listening, reading, and writing (Hussien, 2018; Rohman, 2014). In general, the material in Arabic learning is divided into three parts, namely phonology, morphology, and syntax (Wekke, 2017) and phonology being the basis for mastering speaking and listening skills (Taha \& Haddad, 2016). Meanwhile, from linguistics views, Arabic is a rich language with its vocabulary. One of Arabic privileges is that someone can express their intention using two or hundreds words (Shamsuddin \& Ahmad, 2017). Thus, knowledge of word forms, article functions, pronouns, genders, numbers, to meaning differences caused by the difference of the structure is as the basic knowledge needed when learning Arabic (Zailani et al., 2014).

In its implementation, Arabic subject matter must also be adapted to student conditions (Wekke, 2017) and pay attention to local cultural content (Lewicka \& Waszau, 2017). 
This emphasizes that the characteristics of Arabic learning between countries will be different. Besides, the success of learning Arabic is also influenced by the teacher's role (Al-Omari, 2016), the teaching methods used (Dajani, 2015), and the quality of the textbooks used (Lewicka \& Waszau, 2017). Therefore, to encourage the success of learning Arabic, many variables need attention.

As one of the largest Moslem countries in the world, Indonesia has realized the importance of learning Arabic. Arabic is a compulsory subject in madrasas such as Madrasah Ibtidaiyah (MI), Madrasah Tsanawiyah (MTs), to Madrasah Aliyah (MA). However, an Arabic subject in schools does not guarantee that all students have good Arabic competences. Many cases are found that students who are good at reading Arabic texts/writings like Qur'an and Hadith cannot understand the meaning of those writings. It is indicated that there is a problem with Arabic learning process in Madrassas. The same problem not only happens in Indonesia but also in other Moslem countries in South Asia such as Malaysia and Brunei Darussalam. The research related to Arabic language learning reveals that Arabic learning problems include curriculum, teachers' qualifications, learning materials (Shamsuddin \& Ahmad, 2017, p. 7), to learning orientations that do not meet the main objectives of Arabic language learning (Arief, 2017). Other problems encountered related to learning Arabic are pedagogical approach still using traditional methods (Sakho, 2012; Samah et al., 2016)

In relation to those problems, efforts have been done to improve the learning quality and also improve the students' Arabic skills. Some examples are applied by developing an information technology-based learning (Santoso \& Fitriansyah, 2017), an electronic Arabic dictionary (Omar \& Dahlan, 2011), or an implementation of interactive learning method/model such as blended learning (Alasraj \& Alharbi, 2014), or group work (Awang et al., 2013) to facilitate students when learning Arabic. Some of the efforts that have been recommended are certainly obtained through a study and by looking at problems that occur in the field. Thus, evaluating the achievements of a program (in this case Arabic learning programs in Indonesia) becomes urgent to do (Zurqoni et al., 2018). Through this evaluation, it is expected to know the fundamental problems related to learning Arabic, so that strategies can then be sought to overcome them.

\section{The Objectives of the Study}

A number of studies recommend the need to develop learning materials to facilitate teachers and students in learning Arabic (Hamidin, 2015). Good materials should be able to facilitate students and also teachers to overcome the difficulties they face. However, the difficulties of Arabic language learning in Indonesia especially in madrasah have not been solved yet. Researches to overcome the teachers' and students' difficulties in Arabic learning are needed. Therefore, the researcher is eager to identify the difficulties of madrasah teachers in Arabic language learning. There are three main points of this research, namely: (1) to identify the teachers' difficulties in Arabic language learning in MA; (2) to identify the strategy applied by the teachers to overcome the Arabic language learning difficulties in MA; (3) to identify the teachers' needs to implement Arabic language learning in MA. It is hoped that the teachers will get easy to find out and think about a given solution. 


\section{METHOD \\ Participants}

This was qualitative research with a phenomenological approach. The teachers' difficulties in Arabic learning obtained from 27 Arabic teachers, 9 principals, and 45 students from 9 MA in 3 provinces in Indonesia, those were: East Kalimantan, Special Region of Yogyakarta, and West Nusa Tenggara. These provinces were chosen to represent Indonesia in the western, central, and eastern region. The selection of schools was determined using stratified random sampling, by choosing the schools with the category of high, medium, and low according to the National Examination results. Students involved in this study were students in tenth and eleventh grade (age range 1517 years old) from each school. Information from students is needed as a comparison to information from teachers and principals, as well as additional information to sharpen research findings.

\section{Data Collection Technique}

Broadly speaking, this research used three types of data collection techniques that support one another, those were Focus Group Discussion (FGD), questionnaires, and interviews. FGD was done with the teachers and the principals in every province to obtain Arabic language learning information in every province. Before doing FGD, the respondents (the teachers and the principals) completed the questionnaire. The questionnaire for teachers and principals was used to identify the Arabic language learning difficulties and invited the teachers to give feedback about the urgent things that the teachers needed immediately. The questionnaire consisted of 27 open-ended questions, where respondents were asked to fill in the questionnaire by their knowledge and experience, both as Arabic teachers and as principals. In general, the points asked in the questionnaire included 6 aspects, namely: (1) the achievement of the latest Arabic learning, (2) the Arabic learning curriculum, (3) the challenges of learning Arabic, (4) resources, media, and facilities for learning Arabic, (5) utilizing technology in learning Arabic, and (6) strategies in learning Arabic. Then, respondent responses were elaborated in FGD. The FGD result was to give information about the difficulties and strategies done by the teachers to solve Arabic language learning difficulties. Furthermore, the in depth interview was conducted with some teachers and principals to support the questionnaire and FGD data.

To compare and strengthen data sourced from teachers and principals, researchers also collected data sourced from students. Students were asked to fill in a questionnaire consisting of 21 open questions. In general, the points asked in the student questionnaire included 5 aspects, namely: (1) students' ability in reading, listening, writing, and speaking Arabic; (2) challenges faced by students in learning Arabic; (3) resources, media, and facilities in learning Arabic, (4) utilization of technology in learning Arabic, and (5) students' strategies in learning Arabic.

\section{Data Analysis}

The collected data was analyzed to obtain the description of the teachers' difficulties, the teachers' strategy, and the teachers' Arabic learning needs. For that reason, the data 
was analyzed using a Bogdan \& Biklen (2007) model, to gain the understanding and the description. This data analysis was done during the data collection (in the field) and after the data coding and the data categorization according to the contexts, perceptive, processes, activities, strategies, relationships, and social structures.

All data obtained from questionnaires (from principals, teachers, and students), FGD (involving teachers and principals), and interviews (some teachers and principals) were tabulated and data reduction was then performed. Subsequent data reduction results were categorized based on sub-themes, then from each of the sub-themes, the researchers determines the main themes that represent the findings of the research as a whole. Relationships between components, subthemes, and main themes were then presented through tables.

\section{FINDINGS}

Having been FGD with the teachers in nine madrasas in three Indonesian provinces (Special Region of Yogyakarta, West Nusa Tenggara, and East Kalimantan), some results of the teachers' success of Arabic language learning and the teachers' difficulties of Arabic language learning in MA were obtained. To get the background knowledge of the teachers' difficulties, the obtained information in this research will be discussed into three parts, namely the used curriculum, the learning implementation challenges, and the follow-up efforts of madrassas to improve the success of Arabic language learning. The result description is as follows.

\section{The Success of Arabic Language Learning}

Viewed from the students' competency, nine-madrasa Arabic language learning has not been admitted maximally. There are several indicators mentioned by the teachers in relation to the level of the unsuccessful of Arabic language learning in nine madrassas (see Table 1).

Table 1

The Success of Arabic Language Learning

\begin{tabular}{ll}
\hline Indicators of Unsuccessful & Teachers' Perception of Success Level \\
\hline Students had low learning motivation. & rabic learning had not been \\
Many students did not master reading and writing skills. & implemented successfully. \\
Students had low ability in reading and writing. & \\
Some students achieved scores under the minimum level & \\
of the learning mastery & \\
Students had low vocabulary mastery & \\
\hline $\begin{array}{l}\text { Students answered the questions and applied Arabic in } \\
\text { daily contexts, but still used basic communication. }\end{array}$ & $\begin{array}{l}\text { rabic learning was quite successful but } \\
\text { not optimally implemented, especially } \\
\text { ftudents had low ability in Arabic listening and }\end{array}$ \\
$\begin{array}{l}\text { speaking. } \\
\text { Students achieved the standard level, but still }\end{array}$ \\
experienced many problems. \\
Students achieved the classical minimum level of the \\
learning mastery above $80 \%$, yet they were not fluent \\
in Arabic.
\end{tabular}


Table 1 shows that many things that can be used as evidence of Arabic learning in nine MA have not been successful. In general, the unsuccessful achievement of Arabic learning can be seen from the low motivation of students in learning Arabic and the application of the use of Arabic (specifically speaking) which has not been well implemented in classroom learning activities. This is also a strong indication of the difficulties experienced by students in learning Arabic.

The teachers' evaluation showed several students' difficulties after participating in Arabic language learning process. The students' difficulties generally were on reading comprehension, listening, and speaking in Arabic. Table 2 was seen a number of the students' difficulties factors. Among a number of those factors, four main factors often happened. Those four factors were sentence pattern/structure mastery, vocabulary mastery (including Arabic idioms), self-confidence, and exposure.

Table 2

The Students' Difficulties of Arabic Language Learning

\begin{tabular}{|c|c|c|}
\hline Response & Theme & Conclusion \\
\hline $\begin{array}{l}\text { Difficulty in understanding Arabic } \\
\text { idioms } \\
\text { Lack of vocabulary mastery } \\
\text { Difficulty in understanding tenses in a } \\
\text { sentence/paragraph with appropriate } \\
\text { structure/grammar }\end{array}$ & $\begin{array}{l}\text { Students experienced } \\
\text { difficulty in understanding } \\
\text { the text because of many } \\
\text { unfamiliar words and } \\
\text { idioms. }\end{array}$ & \multirow{12}{*}{$\begin{array}{l}\text { The students } \\
\text { experienced } \\
\text { difficulties } \\
\text { because of lack of } \\
\text { grammatical } \\
\text { structures, lack of } \\
\text { vocabulary } \\
\text { mastery, lack of } \\
\text { self-confidence, } \\
\text { and they were } \\
\text { unfamiliar with } \\
\text { Arabic language }\end{array}$} \\
\hline $\begin{array}{l}\text { Difficulty in writing a } \\
\text { sentence/paragraph due to lack of }\end{array}$ & \multirow{4}{*}{$\begin{array}{l}\text { Low-level of grammatical } \\
\text { structures and limited } \\
\text { vocabulary mastery } \\
\text { hamper the students in } \\
\text { writing }\end{array}$} & \\
\hline $\begin{array}{l}\text { Difficulty in differentiating a sentence } \\
\text { structure based on its tenses (past or } \\
\text { future) }\end{array}$ & & \\
\hline $\begin{array}{l}\text { Difficulty in writing a sentence due to } \\
\text { lack of verb modifications with } \\
\text { appropriate grammatical structure. }\end{array}$ & & \\
\hline $\begin{array}{l}\text { Difficulty in determining pronouns } \\
\text { (subject/object) in sentences based on } \\
\text { the sentence structure }\end{array}$ & & \\
\hline $\begin{array}{l}\text { Lack of self-confidence, being afraid of } \\
\text { making mistakes, being shy to speak }\end{array}$ & \multirow[t]{4}{*}{$\begin{array}{l}\text { Low-level of Arabic } \\
\text { speaking confidence }\end{array}$} & \\
\hline $\begin{array}{l}\text { Lack of vocabulary mastery and } \\
\text { materials }\end{array}$ & & \\
\hline Incorrect pronunciation/articulation & & \\
\hline Incorrect Arabic intonation & & \\
\hline $\begin{array}{l}\text { Lack of Arabic listening and speaking } \\
\text { exposure }\end{array}$ & $\begin{array}{l}\text { Students experienced } \\
\text { difficulty in understanding } \\
\text { Arabic conversations, }\end{array}$ & \\
\hline $\begin{array}{l}\text { Lack of vocabulary or idioms mastery } \\
\text { in played Arabic dialogs/monologs }\end{array}$ & $\begin{array}{l}\text { dialogs, and monologs } \\
\text { because they were } \\
\text { unfamiliar with Arabic }\end{array}$ & \\
\hline Lack of vocabulary mastery & listening & \\
\hline
\end{tabular}




\section{The Challenges of Arabic Language Learning Implementation}

After collecting the data from the madrasa teachers, students, and principles, the information of Arabic language learning implementation in madrasas was obtained. Those were in relation to the main focus or orientation of learning implementation, and Arabic language learning challenges (see Table 3). Both, then, were connected to four Arabic competences which needed to be mastered by the students, namely writing, reading, listening, and speaking. The result of data collection related to both things is presented as follows.

Table 3

Arabic Language Learning Implementation

\begin{tabular}{|c|c|c|}
\hline Response & Theme & Conclusion \\
\hline $\begin{array}{l}\text { Learning was only focused on writing and } \\
\text { reading skills. } \\
\text { Learning was about direct translating a holy } \\
\text { book. } \\
\text { Learning was focused on verb modifications. } \\
\text { Learning was focused on understanding a video } \\
\text { conversation in groups. } \\
\text { Arabic speaking practices were conducted only } \\
\text { in Islamic boarding environment. }\end{array}$ & $\begin{array}{l}\text { Arabic language } \\
\text { learning was not } \\
\text { focused on four } \\
\text { competencies } \\
\text { (reading, writing, } \\
\text { listening, and } \\
\text { speaking) }\end{array}$ & $\begin{array}{l}\text { The focus of Arabic } \\
\text { language learning is } \\
\text { different in every } \\
\text { madrasah based on } \\
\text { the students' needs } \\
\text { and situations. }\end{array}$ \\
\hline $\begin{array}{l}\text { Students were not actively engaged in all of } \\
\text { four competencies. } \\
\text { Students did not actively participate in Arabic } \\
\text { speaking. } \\
\text { Students did not actively participate in Arabic } \\
\text { writing. } \\
\text { Students were good at reading, listening, and } \\
\text { writing skills, but not in speaking (not fluent } \\
\text { enough) } \\
\text { Students were active but still experienced } \\
\text { difficulty in writing full-sentences. }\end{array}$ & $\begin{array}{l}\text { Students' } \\
\text { participation in } \\
\text { learning activities } \\
\text { was not optimal. }\end{array}$ & \\
\hline
\end{tabular}

Generally, the learning focus diversity of nine observed-madrasas was found. However, those nine madrasas seemed to focus more on teaching two out of four Arabic competences. Those were reading and writing since both competences were seen as the important competence mastered firstly in order that the students listen or speak Arabic easily. Therefore, listening and speaking competencies were more taught outside the learning-hours. It was in line with what a number of the teachers and students mentioned and also pin-pointed that most of the classroom learning activities only focused on teaching writing and reading.

"I attempt to teach the students four competencies (writing, reading, listening, and speaking) maximally. However, the class time allotment is more prioritized for teaching writing and reading before teaching listening and speaking."

[teacher_1]

"Speaking and listening are often and effectively more taught in Islamic boarding since they can practice directly without any time limitation like in the class." [teacher_3] "Learning Arabic in the class is generally by reading and writing, but listening and speaking are done in the time of morning muhaddatsah"

[student_2] 
"Usually we do in-class Arabic reading and writing activities. We mostly do out-class Arabic listening and speaking activities."

[student_1]

The limited four-competence Arabic teaching, as discussed above, was not far from a number of obstacles or challenges of Arabic language learning implementation faced by the teachers or school's stakeholders. The data reduction summarized in Table 4 showed that 3 main factors were to be obstacles to Arabic competence teaching. From those three factors, the students' competences and the environments were two main factors mentioned mostly as the main obstacles or challenges of learning implementation.

Table 4

The teachers' Difficulties of Four-Competence Arabic

\begin{tabular}{|c|c|c|}
\hline Response & Theme & Conclusion \\
\hline $\begin{array}{l}\text { Heterogeneous inputs of students. } \\
\text { Heterogeneous students' learning motivation. } \\
\text { Lack of self-confidence in students. } \\
\text { Lack of students' ability in mastering verb } \\
\text { modifications. } \\
\text { Limited vocabulary mastery of students. }\end{array}$ & $\begin{array}{l}\text { Low students' } \\
\text { competencies }\end{array}$ & \multirow{3}{*}{$\begin{array}{l}\text { Teachers' } \\
\text { challenges of } \\
\text { Arabic teaching } \\
\text { were caused by } \\
\text { students' cognitive } \\
\text { and affective } \\
\text { factors, school } \\
\text { environments, and } \\
\text { teachers' } \\
\text { competency. }\end{array}$} \\
\hline $\begin{array}{l}\text { Unsupported school's environment. } \\
\text { Lack of Arabic learning facilities. }\end{array}$ & $\begin{array}{l}\text { Unsupported schools' } \\
\text { environments }\end{array}$ & \\
\hline $\begin{array}{l}\text { Difficulty in designing a learning } \\
\text { method/model to teach Arabic four- } \\
\text { competencies to students. } \\
\text { Lack of time allotment to complete all } \\
\text { materials. }\end{array}$ & $\begin{array}{l}\text { The need to improve } \\
\text { teachers' } \\
\text { competency }\end{array}$ & \\
\hline
\end{tabular}

The students' Arabic low-competency was the input implication or the students' previous degree of educational background. The madrasa teachers and principals stated that the diversity of the students' educational background caused a gap between students graduating from madrasah, Islamic boarding, and public schools in relation to the prior Arabic knowledge.

"Those students' inputs are from various educational backgrounds. Not all of them are from madrasas."

"...even there are Hijaiyah illiterate students"

[principal_1]

students' speaking skill"

blocking the

[teacher_1]

The public schools' students often became a challenge of the schools' stakeholders, especially teachers, since they had not had enough Arabic prior knowledge. Instead of teaching the speaking skill to the students, the teachers had to work hard to establish first reading-writing skills and vocabulary mastery since their knowledge was still limited.

“... the public schools' students are often passive when learning Arabic since their prior knowledge such as vocabulary is still low"

[teacher_5]

"Active students are mostly from boarding schools, while passive students are mostly from public schools"

[teacher_1] 
“...students' participation depends on their background, if their junior high schools are religious-based or Islamic boarding schools, usually they have had enough vocabulary mastery."

[teacher_8]

The students' Arabic low-prior knowledge, especially in vocabulary mastery, happened a lot in both madrasas of the low middle cluster. The same cases also happened in the students' Hijaiyah/Arabic reading skill. In the low and middle level-cluster, 50\% to $70 \%$ students still studied Arabic from the very elementary level. Meanwhile, the high-level cluster got good Arabic-knowledge students with a higher percentage. In other words, a low, middle, and high- level cluster had the same cases of facing the low-priorknowledge students.

In relation to the schools' environments, the teachers said that sometimes the students could not develop their speaking skills because they did not have a partner to practice their speaking skills. It happened because not all students had self-confidence or motivation to develop their Arabic skill. Moreover, it was also due to the limited facilitates' and infrastructures' support such as a language laboratory or other information technologies to support Arabic learning.

'Unsupported schools' environments, the students want to practice their speaking, but no partner"

[teacher_4]

"The applied Arabic learning media is more LCD-based."

[teacher_7]

Regarding the learning planning, even not mentioned a lot, this factor became a big challenge faced by most of the teachers. This learning management was in relation to two things. Firstly, it was in relation to the appropriate method to teach all Arabic competences. Second, the difficulty of the time learning-management considered by the teachers was not enough to finish all materials in accordance with the curriculum content.

The Arabic learning planning was reflected from a number of Arabic teachers' and madrasas-stakeholders' actions. Arabic learning planning was from the used curriculum and the curriculum content of Arabic learning planning. Furthermore, the supporting instruments of Arabic learning sources were to be the author's focus. Those were consulted with related parties (teacher and school stakeholders) to find out how far the Arabic learning planning had been done by madrasas.

The FGD results done by the teachers and to madrasas showed that there were two used curriculums of Arabic learning planning. The first model used Curriculum 2013 (K13) as a guideline of Arabic learning planning. The second model combined K13 and School-Based-Curriculum (SBC). The teachers also stated that the Arabic learning content was matched with the national curriculum so that SBC and K13 were to be the main guideline of Arabic learning planning. It was in line with the use of books published by the Ministry of Religion of the Indonesian Republic in Arabic language learning. Additionally, the teachers also used other books, students' worksheet books, and an Arabic-Indonesian dictionary as a supplementary of Arabic language learning in the class. Also, several teachers said that they used Arabic 'holy book' as a supplementary and enrichments. However, the books' and references' availability 
admitted by the teachers was still so limited that sometimes became the learning process challenges.

Regarding K13 implementation in madrasas, time was as one of crucial issues. The teachers thought that the limited time became a challenge of Arabic learning implementation for them in the class. As an implementation, not all language competencies could be taught maximally in the class.

"The time allotment was so limited to teach all those competencies." [teacher_1]

“...make a full-effort to teach four competencies with this time allotment." [teacher_7]

\section{Strategies to Overcome Arabic Language Learning Difficulties}

A number of efforts were done by madrassas to improve and enhance Arabic students' competencies. The summarized data analysis in Table 5 showed that the teachers and madrassas stakeholders had already improved and enhanced the students' competencies through three main strategies. The first is by conducting extracurricular and training out of students' learning hours to improve the students' understanding level. Second, the teachers gave individual or group additional tasks. The third is by involving the students to join Arabic competitions. Those strategies were intended to improve four Arabic competencies of the students; reading, writing, listening and speaking.

Table 5

Strategies to Overcome Arabic Language Learning Difficulties

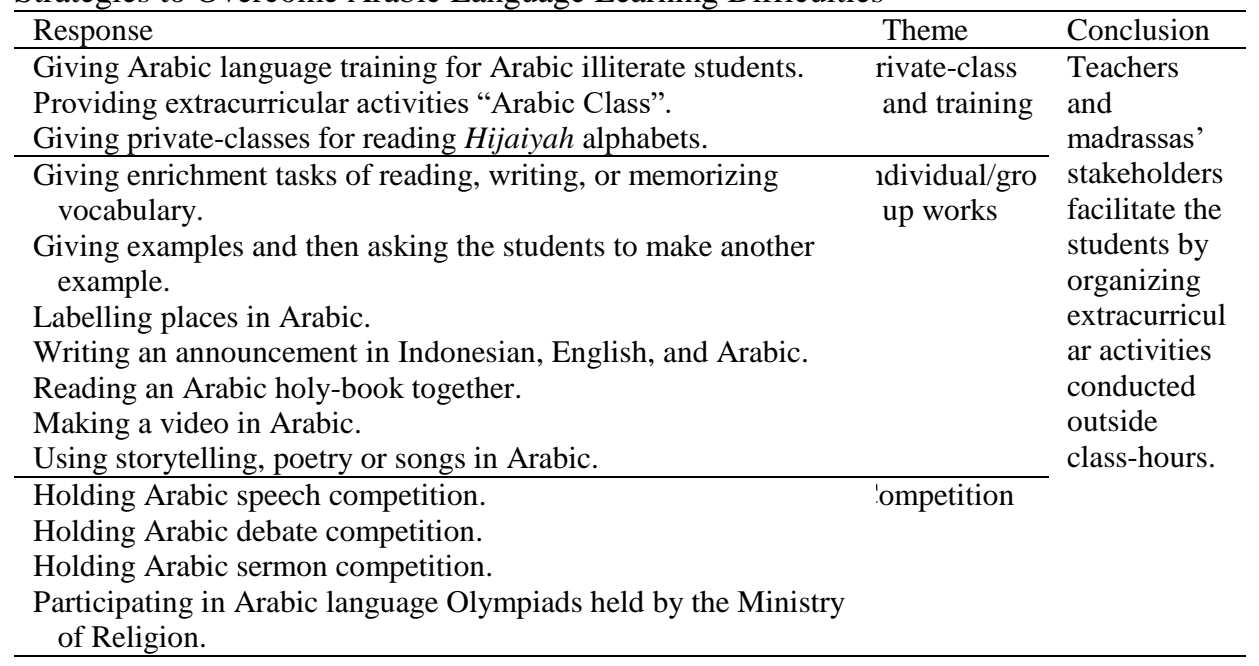

Based on three strategies above, it seemed that the teachers' or madrassas-stakeholders' effort mostly were a language extracurricular. No teachers or schools' stakeholders mentioned explicitly related the implementation of a learning method/approach/model or the use of a learning media. It was because many students' problems were caused by low prior knowledge, like what we had already mentioned in the previous description. Here are several examples of the teachers' response to the implemented strategies to improve students' competency. 
"For students living in an Islamic boarding school but they have not read Hijaiyah yet, they are given special treatment." [teacher_9]

"The students have many opportunities to ask the teachers if they have not understood yet Arabic learning" [teacher_6]

“... to help low vocabulary mastery students, we give task memorization.” [teacher_1]

When the teachers were asked about the used media and content media to teach Arabic successfully, various responses were given. A number of needed media could be categorized into three types; printed media and electronic media. A printed media was references' books and/or literary works. Meanwhile, an electronic media was audio players (e.g. tape recorder) to play conversations, and music/songs containing Arabic vocabulary. An electronic media could also be a visual media such as an electronic dictionary to translate, or an audio-visual to play short movies, animations, Arabic native speaker videos.

"...in my opinion, it is very possible to use it as Arabic learning media, but not all schools

allow the use of smartphones in the school."

[teacher_10]

In relation to a smartphone, the teachers and madrassas' stakeholders argued that a smartphone was very possible to use in teaching Arabic in the class. Some teachers also said about the smartphone restriction and prohibition in a classroom learning process in a number of schools. Nevertheless, some teachers stated that a smartphone should be used as an Arabic learning media or device.

\section{DISCUSSION}

The success of Arabic language learning can be assessed in several aspects. Rakhlin et al. (2019), in their study developed instruments to assess the Arabic skill development of 3 to 11 years old students. The main aspects of their assessment are reading assessment, writing assessment, and speaking assessment. Rohman (2014) argues that Arabic skills consist of four aspects, namely listening (mahârat al-istima), speaking (mahârat al-kalâm), reading (mahârat al-qirâ'at), and writing (mahârat al-kitâbah). When viewed from those four aspects, the results of Arabic language learning implemented by nine madrassas that are our respondents have not showed signs of success yet. The information from nine madrassas described in the above FGD results is the evidence that students' Arabic reading, writing, and speaking skills still needs to be improved. Ideally, the results of Arabic language learning that have been done by the students can give knowledge and skills well. In other words, there are problems' or obstacles' indications during the learning process.

The difficulties of Arabic language learning found in this research occurs in four competencies (reading, writing, listening, and speaking). This research phenomenon is in line with the results of other researches that also discuss a number of Arabic learning difficulties. As an example, students' writing and speaking difficulties have encouraged Rakhlin et al. (2019) to develop a standardized instrument to assess Arabic skills to find out the causes of students' difficulties. In addition, the difficulties in understanding Arabic texts are also found in the research done by Saeed and Fareh (2006). In their research of the 50 English-major Arab students studying at the University of Sharjah, they reveal findings of the students' difficulty in understanding/translating "fa" in a 
sentence or reading based on its function. Adila (2019) in her research stated that one of the difficulties experienced by students in learning Arabic is writing. This is indicated by the number of grammatical errors that occur when students are asked to arrange sentences or paragraphs in Arabic. In addition, learning strategies or models that are still traditionally used also cause students' Arabic language skills not to increase significantly (Hussien, 2018; Jwaifell et al., 2018; Kuraedah, et al., 2018; Omari, 2015; Wekke, 2015)

The most common factor of difficulties argued by nine madrasah teachers is vocabulary mastery. Vocabulary mastery is one of the most crucial factors in the vocabulary mastery, including Arabic. The more vocabulary the students master, the easier the students master Arabic. In their research, Masrai and Milton (2017) reveals the results of the amount of vocabulary needed to master Arabic well. They mention "25,000 words sets a standard for learners to achieve if they aspire to native-like" (Masrai \& Milton, 2017). Although 25,000 is not a rigid or must number, the research results show that vocabulary mastery is the key to master a language.

In addition, Arabic exposure needs environments supporting the students to practice their oral communication between other students. An exposure absence as a media exposure for practicing Arabic skills will hamper the development of their Arabic skills. Moreover, Arabic is not a mother tongue which is the majority language used by the students in the daily lives in Indonesia. This case is in line with the findings of DePalma (2015) who reveals the results of the students' difficulty in finding exposure places to practice their foreign language. It has become one of the factors hampering the development of the students' skills in practicing Arabic as a foreign language.

Arabic language learning that has not showed the results maximally encourages and madrassas' stakeholders to take needed action to overcome those problems. As a result of FGD we have explained, it reveals that the strategies to overcome various Arabic learning difficulties are still limited in the out-class activities of Arabic learning. No one states about the teachers' planning model/strategy/approach of the Arabic learning implementation. In fact, the planning of a learning model/strategy/approach done by the teachers is one of the keys of learning success (Retnawati et al., 2018).

Referring to a number of Arabic language learning researches, it is found a number of strategies to improve the students' Arabic skills. One of the applied strategies is by implementing blended learning. Alasraj and Alharbi (2014) in their study find that the elearning website used in blended learning can help the students to share the experiences of their peers within the e-learning website.

In addition, Arabic language learning also needs to apply collaborative learning principles to help the students develop their Arabic skills. Cooper et al. (2008) outline three strategies of collaborative learning activities: (1) other-directed explaining, which occurs when one peer instructs another, (2) co-construction, in which both peers either elaborate or critique each other's contributions, and (3) self-explanation, listening to one peer self-explain. There are a number of research results of collaborative learning in Arabic as a reference. Alwaleedi et al. (2018) conducted research to find out the effect 
of collaborative learning implementation toward the students' Arabic-writing skill. In their research, they find out that a collaborative writing task has a positive effect to improve writing skills in Arabic as a second language context. To collaborate, not only can it be done offline but also online. In research of Alasraj and Alharbi (2014), they argue that the use of information technology such as the internet in Arabic learning is very necessary for the present and future.

"...the use of the internet can make learning more enjoyable and effective for students, as well as motivate them to meet the course learning objectives. Specifically, the internet allows teachers to provide more opportunities for students to interact with diverse lesson content and to give students greater flexibility over learning activities. "(Alasraj \& Alharbi, 2014, p. 16)

Collaborative learning principles can also be applied to strengthen students' Arabiclistening-and-speaking skills. It can be done by involving the students in group work activities. The designed learning activities can help to increase the level of confidence among students, especially students who are shy, easily gets panic and afraid of making mistakes to speak Arabic. The research done by Awang et al. (2013) found that group work activities are effective to develop speaking skills among students. However, they also stated that the teachers' ability to implement group work activities in the Arabic leaning process also became an important factor of Arabic language learning success.

An assessment of the students' Arabic learning difficulties also needs to be teachers' and madrasas' concerns. The diagnostic test device developed by Rakhlin et al. (2019) can be used to map the students' Arabic difficulties. Hopefully, the assessment results using standardized measurement devices will give challenges and well-developed information. Thus, the teachers can plan the intervention in accordance with the students' needs. Also, the use of technology is important to improve students' Arabic language skills, such as the use of Computer-Assisted Language Learning (Omari, 2015), integrating Flipped Classroom (Jwaifell et al., 2018), or using Arabic Language Software (AlBusaidi et al., 2016)

\section{CONCLUSION AND SUGGESTIONS}

This study shows that Arabic learning has not been successfully implemented. Several difficulties were experienced by the teachers and students during the learning process. Those teachers' and students' learning difficulties are due to several factors, including input factors of students who unable to read Arabic fluently and basic vocabulary mastery, factors of Arabic verb modifications, factors of limited learning hours for nonboarding MA's students, limited learning facilities, and incomplete environmental supports to give the students' opportunity to speak more-Arabic, and also lack of unstandardized Arabic language tests conducted at schools.

Various improvements in Arabic learning can be attempted. The matriculation activities are needed to be done in tenth grade (first year) of MA in Indonesia to level the Arabic mastery of early grade students, with the materials designed based on the students' needs. The need for the development of Arabic learning media is integrated with the use of technology, such as smartphone-based media, online-based media, computer-based 
interactive media, digital Arabic dictionaries, and others. The facilities' and infrastructures' development is also needed, including to facilitate the students' activities for practicing language competencies such as listening, reading, and writing. The standardized test to assess the Arabic language mastery is also needed so that the students' performance can be monitored. This test mastery can also be used to diagnose the students' Arabic language learning difficulties and Arabic language learning improvement in the class. Furthermore, the qualitative findings in this study should be used as a basis for other researchers to investigate appropriate interventions to increase the success of Arabic learning, as well as explore more deeply about best practices for success in learning Arabic.

\section{REFERENCES}

Adila, W. (2019). A written grammatical error analysis of second year students of Arabic. Journal of Arabic Studies, 4(1), 31-44. http://dx.doi.org/10.24865/ajas.v4i1.141.

Alasraj, A., \& Alharbi, H. (2014). The effectiveness of blended learning in teaching Arabic as a second language. International Journal of Research in Humanities and Social Studies, 1(1), 13-17.

Al-Busaidi, F., Al Hashmi, A., Al Musawi, A., \& Kazem, A. (2016). Teachers' perceptions of the effectiveness of using Arabic language teaching software in Omani basic education. International Journal of Education and Development using Information and Communication Technology, 12(2), 139-157.

Al-Omari, F. (2016). Teaching Arabic language for non-native speakers in the light of modern linguistics. Dirasat, Human and Social Sciences, 43(3), 2529-2536.

Alwaleedi, M. A., Gillies, R. M., \& Hamid, M. O. (2018). Collaborative writing in Arabic as a second language (ASL) classrooms: A mixed-method study. Language, $\begin{array}{llll}\text { Culture and } & \text { Curriculum, } & \text { 157-172. }\end{array}$ https://doi.org/10.1080/07908318.2018.1521422.

Arief, A. F. (2017). The degree of difficulty of Indonesian people in learning Arabic. Advance Research Journal of Multidisciplinary Discoveries, 11(1), 27-34.

Awang, N. A. B., Mohamed, M. H. B., \& Sulaiman, R. B. (2013). Enhancing Arabic speaking skills among Malay students through group work activities. International Journal of Humanities and Social Science, 3(21), 212-219.

Bogdan, R. C., \& Biklen, S. K. (2007). Naturalistic inquiry and the saturation concept: A research note. Qualitative Research, 8(1), 137-152. https://doi.org/10.1177/1468794107085301.

Cooper, M. M., Cox, C. T., Nammouz, M., Case, E., \& Stevens, R. (2008). An assessment of the effect of collaborative groups on students' problem-solving strategies and abilities. Journal of Chemical Education, 85(6), 866-872. https://doi.org/10.1021/ed085p866. 
Dajani, B. A. S. (2015). Teaching Arabic language: Towards a new beginning that stimulates creativity. Procedia-Social and Behavioral Sciences, 92, 758-763. https://doi.org/10.1016/j.sbspro.2015.06.086.

DePalma, R. (2015). Learning a minoritized language in a majority language context: Student agency and the creation of micro-immersion contexts. International Journal of Bilingual Education and Bilingualism, 18(4), 426-442. https://doi.org/10.1080/13670050.2014.916653.

Hamidin, N. M. (2015). Effective technique of teaching and learning Arabic language in the classroom: A case study in selected national religious secondary schools (SMKA) in Selangor. In The International Conference on Language, Culture, and Education (pp. 113-118). Singapore.

Hussien, A. M. (2018). Culture of traits in Arabic language education: Students' perception of the communicative traits model. International Journal of Instruction, 11(4), 467-484. https://doi.org/10.12973/iji.2018.11429a.

Jwaifell, M., Abu-Omar, R., \& Al-Tarawneh, M. (2018). The readiness of arabic language teachers for integrating flipped classroom: Case of Ma'an. International Journal of Instruction, 11(4), 855-868. https://doi.org/10.12973/iji.2018.11454a.

Kuraedah, S., Mar, N. A., \& Gunawan, F. (2018). Improving students' sense to learn language in islamic institution of coastal area Indonesia. IOP Conference Series: Earth and Environmental Sciece, 156, 1-8. https://doi.org/10.1088/1755-1315/156/1/012047.

Lewicka, M., \& Waszau, A. (2017). Analysis of textbooks for teaching Arabic as a foreign language in terms of the cultural curriculum. Universal Journal of Educational Research, 5(1), 36-44. https://doi.org/10.13189/ujer.2017.050105.

Masrai, A., \& Milton, J. (2017). How many words do you need to speak Arabic? An Arabic vocabulary size test. The Language Learning Journal, 47(5), 1-18. https://doi.org/10.1080/09571736.2016.1258720.

Mat, H., \& Wan Abas, W. M. U. (2016). The relevance of arabic language in islamic studies program: a case study of Open University Malaysia (OUM). Journal of Education and Social Sciences, 5(2), 205-209.

Omar, C. A. M. B. C., \& Dahlan, H. B. A. M. (2011). The development of e-dictionary for the use with Maharah Al-Qiraah textbook at a matriculation centre in a university in Malaysia. TOJET: The Turkish Online Journal of Educational Technology, 10(3), 255264.

Omari, S. E. (2015). The Effect of computer-assisted language learning on improving arabic as a foreign language (AFL) in higher education in the United States. ProcediaSocial and Behavioral Sciences, 192, 621-628. https://doi.org/10.1016/j.sbspro.2015.06.109.

Rakhlin, N. V, Aljughaiman, A., \& Grigorenko, E. L. (2019). Assessing language development in Arabic: The Arabic language: Evaluation of function (ALEF). Applied 
Neuropsychology: Child, 1-16. https://doi.org/10.1080/21622965.2019.1596113.

Retnawati, H., Djidu, H., Kartianom, K., Apino, E., \& Anazifa, R. D. (2018). Teachers' knowledge about higher-order thinking skills and its learning strategy. Problem of Education in the 21st Century, 76(2), 215-230.

Rohman, F. (2014). Strategi penglolaan komponen pembelajaran bahasa Arab [Strategy for managing Arabic learning components]. Jurnal Pendidikan Bahasa Arab Dan Kebahasaaraban, 1(1), 63-78.

Saeed, A. T., \& Fareh, S. (2006). Difficulties encountered by bilingual Arab learners in translating Arabic 'fa' into English. International Journal of Bilingual Education and Bilingualism, 9(1), 19-32. https://doi.org/10.1080/13670050608668628.

Sakho, M. L. (2012). Teaching Arabic as a second language in international school in Dubai: A case study exploring new perspectives in learning materials design and development (Unpublished doctoral dissertation). The British University in Dubai.

Samah, R., Puteh-Behak, F., Saad, N. S. M., Ali, S. M., Darmi, R., \& Harun, H. (2016). Effective methods in learning Arabic language as a foreign language. Mediterranean Journal of Social Sciences, 7(3), 349-355. https://doi.org/10.5901/mjss.2016.v7n3p349.

Santoso, H. B., \& Fitriansyah, R. (2017). Prototype development and usability evaluation of a mobile-based Arabic language learning application. Journal of Engineering and Applied Sciences, 12(8), 1961-1967.

Shamsuddin, S. M., \& Ahmad, S. S. B. H. (2017). Contemporary issues of teaching Arabic in Southeast Asian Countries (Brunei, Malaysia and Indonesia for the example). Journal of Research in Humanities and Social Science, 5(6), 42-51.

Taha, H. \& Haddad, E. S. (2017). Morphology and spelling in Arabic: Development and interface. Journal of Psycholinguistic Research, 46(1), 27-38.

Wekke, I. S. (2014). Arabic teaching and learning: A model from Indonesian muslim minority. Procedia-Social and Behavioral Sciences, 191, 286-290. https://doi.org/10.1016/j.sbspro.2015.04.236.

Wekke, I. S. (2017). Arabic teaching and learning material in higher education of muslim community North Sulawesi. Dinamika Ilmu, 17(2), 175-189. https://doi.org/10.21093/di.v17i2.863.

Zailani, S., Zainal, H., Ghani, S. A., Osman, K., Ismail, Z., \& Hashim, U. H. (2014). Public need for an arabic language teaching and learning module: Using Al-Qur'an approach. Mediterranean Journal of Social Sciences, 5(29), 54-61. https://doi.org/10.5901/mjss.2014.v5n29p54.

Zurqoni, Z., Retnawati, H., Apino, E., Anazifa, R. D. (2018). Impact of character education implementation: A goal-free evaluation. Problems of Education in the 21st Century, 76(6), 881-899. 